\title{
Chondroid Hamartoma
}

National Cancer Institute

\section{Source}

National Cancer Institute. Chondroid Hamartoma. NCI Thesaurus. Code C42589.

A hamartoma that is characterized by the presence of chondroid elements. 